\title{
Canadian bioweapons
}

\author{
Pathogens for War: Biological Weapons, \\ Canadian Life Scientists, and North \\ American Biodefence \\ Donald Avery \\ University of Toronto Press; 2013
}

$\mathrm{P}$ erhaps you've heard the incredible stories: in Kingston, Ontario, a Queen's University laboratory was weaponizing anthrax during World War II; a simulated attack released bacteria over Winnipeg, Manitoba; Canadian scientists tested American chemical and biological weapons in Suffield, Alberta, throughout the 1960s.

It's true, all true. Finally, we have solid evidence of these long-whispered tales. Donald Avery's scholarly examination of Canada's involvement with bioweapons begins in 1940 when Dr. Frederick Banting warned of possible germ warfare, and it carries on to the present, covering major conflicts, terrorist attacks and growth in the scientific understanding of pathogens and their intimate connections to public health. Avery situates Canada's involvement within what is known of pro-

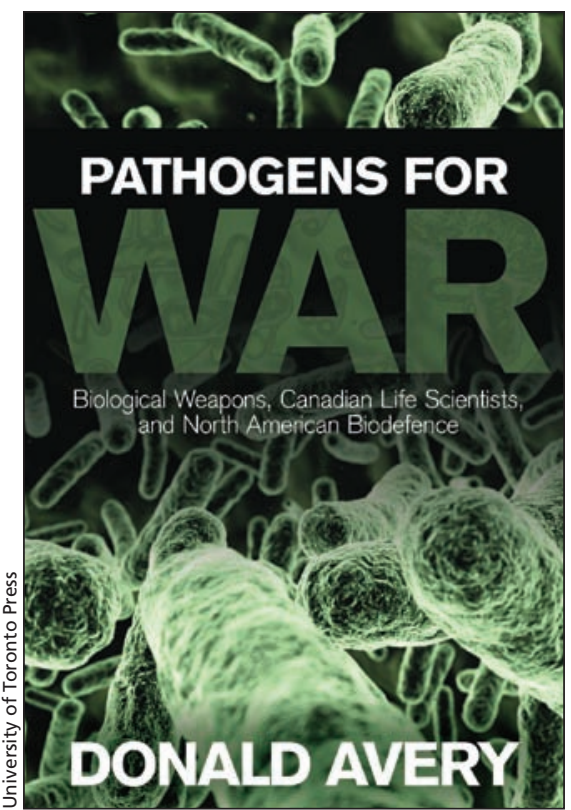

bombs as part of a plan to end the war. The UK and the US opposed Canada's plan to vaccinate soldiers against botulism before ever using it on the enemy. They argued that their own unprotected troops might suffer psychological stress upon learning that their Canadian counterparts had been vaccinated. Indeed, danger to Allied troops and the inability

\section{Avery examines the growth in scientific understanding of pathogens and their intimate connections to public health.}

grams in the United Kingdom, the United States, Russia and the former Soviet Union. The fearful possibility that an enemy might resort to illegal weapons prompted those governments to develop bioweapons as well.

Avery uncovers many disturbing details regarding Allied use of biologicals during World War II: for example, they prepared millions of anthrax cluster to ever occupy lands where biologicals had been released were the greatest inhibitions to their use.

Notwithstanding President Nixon's 1969 decision to abandon biological warfare ("If someone uses germs on us, we'll nuke them") and the 1975 international agreement to outlaw them completely, the former Allies continued to investigate bioweapons while vigor- ously denying it. A deadly anthrax leak at Sverdlovsk exposed but did not stop the Soviet Union's duplicity; this "biological Chernobyl" claimed dozens if not hundreds of lives in 1979.

The offensive use of pathogens is inextricably entwined with defensive planning by both military and health care professionals who prepare for natural or deliberate attacks. The now familiar and more anodyne phrases of "pandemic planning" or "disaster planning" originated in the legacy of scientists who worked diligently on the lethal programs at taxpayer expense.

No country takes pride in its bioweaponry past. They invoke "security issues" as a pretext for secrecy or deception. Consequently, Avery's difficult research took two decades to accomplish and multiple access-to-information requests. It relies on a vast array of archival material, many interviews and hundreds of government documents. His work also encompasses controversial recent events, for which the media is the only source; for example, the anthrax letter scare of 2001 and the possible role of American microbiologist Bruce Ivins, who committed suicide in 2008.

Avery closes with an informed analysis of the bioweapon capability of terrorist groups active in the world today. His meticulous book brings this shadowy past out of the realm of rumour, sheds light on its people, pathogens and procedures, and shows that the threatening potential for biological warfare remains.

\section{Jacalyn Duffin MD PhD \\ Professor \\ Hannah Chair of the History of Medicine Queen's University \\ Kingston, Ont.}

CMAJ 2014. DOI:10.1503/cmaj.131730 